Article

\title{
Simultaneous Leaching of Seafloor Massive Sulfides and Polymetallic Nodules
}

\author{
Przemyslaw B. Kowalczuk ${ }^{1, *} \mathbb{C}$, Hassan Bouzahzah ${ }^{2}$, Rolf Arne Kleiv ${ }^{1}$ and Kurt Aasly ${ }^{1} \mathbb{C}$ \\ 1 Department of Geoscience and Petroleum, NTNU Norwegian University of Science and Technology, \\ S. P. Andersens veg 15a, 7031 Trondheim, Norway \\ 2 GeMMe, University of Liege, Allée de la Découverte 9, 4000 Liège, Belgium \\ * Correspondence: przemyslaw.kowalczuk@ntnu.no
}

Received: 9 July 2019; Accepted: 8 August 2019; Published: 10 August 2019

\begin{abstract}
Simultaneous leaching of seafloor massive sulfides (SMS) from Loki's Castle on the Arctic Mid-Ocean Ridge (AMOR) and polymetallic nodules (PN) from Clarion Clipperton Zone (CCZ) of the Central Pacific Ocean was studied. Leaching tests were conducted using sulfuric acid and sodium chloride, at a temperature of $80^{\circ} \mathrm{C}$ for $48 \mathrm{~h}$ under reflux. The effect of PN-to-SMS ratio was examined. It was shown that simultaneous leaching of two different types of marine resources was possible resulting in high dissolution rates of metals. The proposed process has many advantages as it does not require pyrometallurgical pretreatment, and yields solid products (i.e., silica, barite, elemental sulfur, albite, microcline, muscovite), which might be utilized for various industrial applications.
\end{abstract}

Keywords: polymetallic nodules; seafloor massive sulfides; leaching; copper; manganese; deep-sea mining

\section{Introduction}

Polymetallic nodules (PN), iron-manganese crusts (Fe-MnC) and seafloor massive sulfides (SMS) deposits, due to their high content of various economically important metals (i.e., $\mathrm{Cu}, \mathrm{Ag}, \mathrm{Zn}, \mathrm{Mn}$, REE, etc.), have been identified as important marine mineral resources for the future [1,2]. Each type of deposit presents individual challenges at every stage of exploration, exploitation, and metal extraction cycle [3]. SMS are metallic sulfide ores, while PN and Fe-MnC are metallic oxide ores, thus their processing requires different methodologies. Whereas sulfides are conventionally processed by flotation [4], leaching has become an efficient method for the extraction of metals from oxides [5].

The complex mineralogy and rapid oxidation of SMS provide challenges to conventional beneficiation by flotation [6-8], thus a new process to extract metals simultaneously by leaching of SMS and PN is proposed in this paper. The simultaneous leaching of manganese dioxide and sulfides such as chalcopyrite [9,10], sphalerite [11], and pyrite [12] in acid media has been investigated. In our previous paper [8], we showed that the dissolution rate of metals from SMS was accelerated in the presence of $\mathrm{MnO}_{2}$ in the $\mathrm{H}_{2} \mathrm{SO}_{4}-\mathrm{NaCl}$ media. This acceleration was interpreted to be a result of galvanic interactions between the sulfide minerals of the SMS ore, such as chalcopyrite $\left(\mathrm{CuFeS}_{2}\right)$, isocubanite $\left(\mathrm{CuFe}_{2} \mathrm{~S}_{3}\right)$, sphalerite $((\mathrm{Zn}, \mathrm{Fe}) \mathrm{S})$, pyrite/marcasite $\left(\mathrm{FeS}_{2}\right)$, and manganese dioxide $\left(\mathrm{MnO}_{2}\right)$. We suggested that polymetallic nodules might serve as a potential source of $\mathrm{MnO}_{2}$ acting as an oxidant for leaching of metals from SMS. Furthermore, PN contain not only manganese and iron but also other economically important metals such as copper, nickel, cobalt etc., which can be recovered during leaching of a mixture of SMS and PN. However, to date, no paper has been published on simultaneous leaching of SMS and PN. Our approach considers the mixed $\mathrm{H}_{2} \mathrm{SO}_{4}-\mathrm{NaCl}$ system, which is efficient and less expensive than leaching in pure chloride systems [13-15]. The successful development of such a process offers an attractive alternative to pyrometallurgical processing, as it offers the prospect 
of eliminating gas emission, production of potentially recoverable solid residues and generation of acid, which could be recycled to the head of the process. The new approach holds promise for efficient processing of marine mineral resources.

\section{Materials and Methods}

\subsection{Materials}

This study utilizes an SMS sample collected from the Loki's Castle active hydrothermal vent field at the Arctic Mid-Ocean Ridge (AMOR), which occurs on the Mohn's Ridge at a depth of approximately $2400 \mathrm{~m}$ [16]. The SMS samples were collected as a part of the MarMine cruise [17]. More than $200 \mathrm{~kg}$ of loose boulders from the mound flanks were collected via grab sampling. The location and areas of operation are described elsewhere $[7,17,18]$. In order to prevent oxidation of sulfides, the collected rock samples were bagged, flushed with nitrogen, vacuum sealed, and stored at $-21^{\circ} \mathrm{C}$.

The polymetallic deep-sea nodules (PN) studied in this research were collected in the license area of Global Sea Mineral Resources (GSR) from Clarion Clipperton Zone (CCZ) of the Central Pacific Ocean. The samples were stored in plastic bags.

Mili-Q water ${ }^{\circledR}$ and analytically grade $\mathrm{H}_{2} \mathrm{SO}_{4}$ and $\mathrm{NaCl}$ were used in the experiments.

\subsection{Methods}

Prior to characterization and leaching experiments, the SMS sample was unpacked and dried at room temperature $\left(25^{\circ} \mathrm{C}\right)$, while the PN samples were dried in a drying cabinet at $60^{\circ} \mathrm{C}$. Then, the individual rock samples were crushed using a jaw crusher (Retsch $\mathrm{GmbH}$, Haan, Germany), ground in a disc mill (Retsch $\mathrm{GmbH}$, Haan, Germany), and sieved to obtain $100 \%$ finer than $50 \mu \mathrm{m}$, with a $d_{50}$ of $10 \mu \mathrm{m}$.

A known mass of feed for leaching $(7.5 \pm 0.05 \mathrm{~g})$ consisting of either pure SMS, PN or their mixtures at different ratios, together with $150 \mathrm{~cm}^{3}$ of $1.0 \mathrm{M}$ sulfuric acid $\left(\mathrm{H}_{2} \mathrm{SO}_{4}\right)$ and $1 \mathrm{M}$ sodium chloride $(\mathrm{NaCl})$ were added to $250 \mathrm{~cm}^{3}$ reaction flasks. Then, the flasks were placed in the Carousel 6 Plus reaction station from Radley's Innovation Technology, stirred at $700 \mathrm{rpm}$, and heated to $80^{\circ} \mathrm{C}$. Leaching experiments were conducted for $48 \mathrm{~h}$ under reflux.

Leachate was collected periodically, filtered using a $32 \mathrm{~mm}$ syringe filter with $0.2 \mu \mathrm{m}$ Supor ${ }^{\circledR}$ membrane, diluted 10-times using $1.0 \%(v / v) \mathrm{HNO}_{3}$, and then analyzed at NTNU using inductively coupled plasma mass spectroscopy (ICP-MS, PerkinElmer SCIEX-ELAN DRC II, Waltham, MA, USA).

The leaching residues were dried at $60{ }^{\circ} \mathrm{C}$ prior to chemical and mineralogical analyses. The bulk chemical composition of the leaching feed and residues was analyzed at NTNU with ICP-MS and X-ray fluorescence (XRF, ThermoScientific, Waltham, USA). A $2 \mathrm{~g}$ of solid sample and $20 \mathrm{~cm}^{3}$ of concentrated nitric acid were added to a $100 \mathrm{~cm}^{3}$ closed Erlenmeyer flask. The mixture was placed on a hot plate and heated to $85^{\circ} \mathrm{C}$ for $20 \mathrm{~h}$. After digestion, the sample was cooled to the room temperature, filtered, diluted to $50 \mathrm{~cm}^{3}$, and then analyzed.

The mineralogy was determined by using semi-quantitative X-ray diffraction (XRD) at NTNU, and automated mineralogy (AM) at GeMMe. The XRD patterns were collected using a Bruker D8 Advanced XRD (Billerica, MA, USA), using CuK alpha radiation with a wavelength of $0.154056 \mathrm{~nm}$ taking measurements between $3-65^{\circ} 2 \theta$ at a step size of $0.01^{\circ} 2 \theta \mathrm{s}^{-1}$. The mineral phases were identified by the use of diffract.Eva software. For automated mineralogy, ca. $1 \mathrm{~g}$ of representative sample was embedded in a mixture of $0.4 \mathrm{~g}$ carbon powder, $15 \mathrm{~cm}^{3}$ epoxy resin and $2 \mathrm{~cm}^{3}$ hardener in order to obtain blocks of $2.5 \mathrm{~cm}$, which were then polished [19]. The polished blocks were observed by optical microscopy and analyzed using a ZEISS Sigma 300 field emission scanning electron microscope fitted with two Bruker xFlash $6 \mid 30$ X-ray detectors for energy-dispersive X-ray spectroscopy (EDX) analysis. The mineral composition was analyzed using Mineralogical Mining System from Zeiss Ltd. (Oberkochen, Germany). The operating conditions for data acquisition were as follows: $20 \mathrm{kV}$ 
acceleration voltage, $3 \mu \mathrm{m}$ step size, and 30.000 number of analyzed particles. More details about the AM can be found elsewhere [20].

The leaching efficiency (recovery) of metals was calculated based on the amount of leached metal in the leachate with respect to the concentration of metal in the feed. The results were obtained from at least three determinations at a $95 \%$ confidence interval.

\section{Results and Discussion}

\subsection{Material Characterization}

Figure 1 illustrates the mineralogical phases of SMS sample, while Figure 2 and Table 1 show the SEM-EDS analyses of the leaching feed for a mixture of PN (67\%) and SMS (33\%), as an example. Mineralogy of this particular leaching feed is discussed in Section 3.3.

The investigated SMS sample represents the hydrothermal vent fragments. Each collected sample represents different bulk chemistry and mineralogy. A detailed characterization of SMS rock samples from AMOR is provided by Snook et al. [18]. The SMS samples were characterized using ICP-MS, XRD, XRF, optical microscopy, and automated mineralogy. Briefly, the SMS sample investigated in this work was very porous and heterogeneous comprising the following mineralogical phases determined by XRD: Quartz $\left(\mathrm{SiO}_{2}\right.$, ca. 36.8\%) with trace barite $\left(\mathrm{BaSO}_{4}\right.$, ca. $\left.1.0 \%\right)$, pyrite/marcasite (ca. 38.2\%), sphalerite (ca. 12.1\%), galena (ca. 1.0\%), isocubanite (ca. 4.7\%), chalcopyrite (ca. 2.5\%) and others (ca. 3.7\%). Chalcopyrite, isocubanite and sphalerite showed complex intergrowth textures with chalcopyrite lamellae within isocubanite, and sphalerite (Figures 1 and 2). Homogenous sphalerite contained up to $20 \%$ of Fe (Table 1). In this work, the sample containing $2.0 \% \mathrm{Cu}, 7.4 \% \mathrm{Zn}, 21.0 \% \mathrm{Fe}$, $26.9 \% \mathrm{~S}, 2.8 \% \mathrm{~Pb}, 12.0 \% \mathrm{Si}, 0.1 \% \mathrm{Ba}$, was used.

Figure $2 \mathrm{~b}$ shows that polymetallic nodules represent the typical heterogeneous layer growth structure with the crystal structure of Mn-oxides and Mn-Fe(oxy) hydroxides being intergrown on a submicron scale. The major minerals for manganese and iron are todorokite $(\mathrm{Na}, \mathrm{Ca}, \mathrm{K})_{2}\left(\mathrm{Mn}^{4+}, \mathrm{Mn}^{3+}\right)_{6} \mathrm{O}_{12} \cdot 3-4.5\left(\mathrm{H}_{2} \mathrm{O}\right)$, birnessite $\left.(\mathrm{Na}, \mathrm{Ca}, \mathrm{K})_{0.5}\left(\mathrm{Mn}^{4+}, \mathrm{Mn}^{3+}\right)_{2} \mathrm{O}_{4} \cdot 1.5 \mathrm{H}_{2} \mathrm{O}\right)$, buserite $\left(\mathrm{Na}_{4} \mathrm{Mn}_{14} \mathrm{O}_{27} \cdot 21 \mathrm{H}_{2} \mathrm{O}\right)$, manganite $(\mathrm{MnOOH})$, vernadite $\left(\mathrm{Mn}^{4+}, \mathrm{Fe}^{3+}, \mathrm{Ca}, \mathrm{Na}\right)(\mathrm{O}, \mathrm{OH})_{2} \cdot \mathrm{nH}_{2} \mathrm{O}$, goethite $(\mathrm{FeOOH})$, magnetite $\left(\mathrm{Fe}_{3} \mathrm{O}_{4}\right)$ or hematite $\left(\mathrm{Fe}_{2} \mathrm{O}_{3}\right)([21]$, chemical formulae based on [22]). Muscovite $\left(\mathrm{KAl}_{2}\left(\mathrm{Si}_{3} \mathrm{Al}\right) \mathrm{O}_{10}(\mathrm{OH}, \mathrm{F})_{2}\right)$, microcline $\left(\mathrm{KAlSi}_{3} \mathrm{O}_{8}\right)$, albite $\left(\mathrm{NaAlSi}_{3} \mathrm{O}_{8}\right)$ and quartz $\left(\mathrm{SiO}_{2}\right)$ were the analysed silicates (chemical formulae based on [22]). The investigated PN contained 27.7\% Mn, 5.5\% $\mathrm{Fe}, 1.3 \% \mathrm{Ni}, 1.1 \% \mathrm{Cu}, 0.12 \% \mathrm{Zn}$.

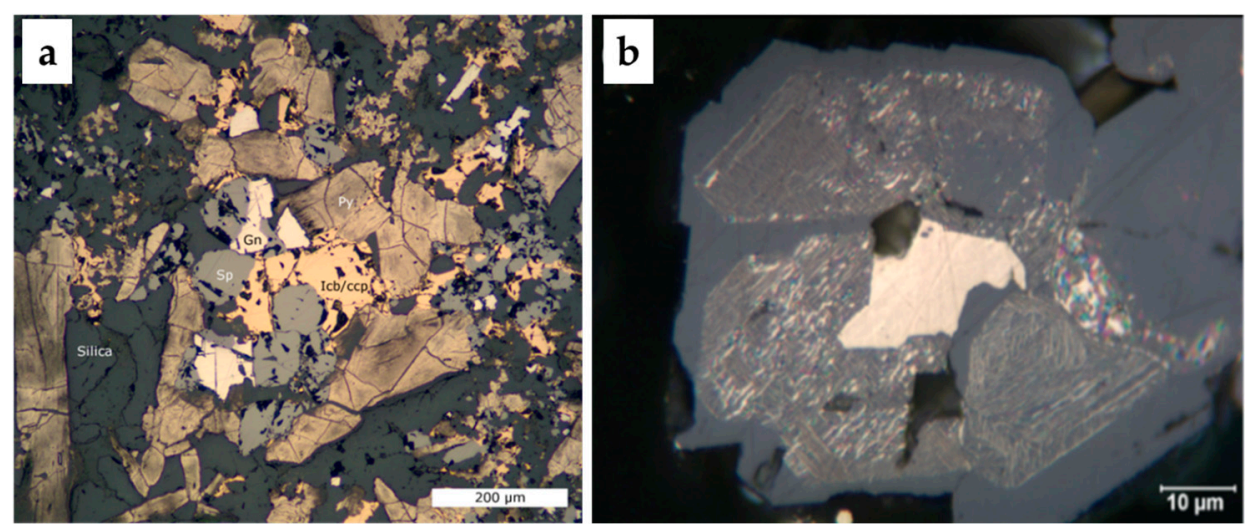

Figure 1. (a) Photomicrographs (under reflected light) demonstrating seafloor massive sulfides (SMS) mineralogy and texture, (b) sphalerite and isocubanite-chalcopyrite texture, sphalerite (grey) with strong chalcopyrite disease (yellow), the centre yellow grain is an intergrowth of isocubanite and chalcopyrite (after [8]). Abbreviations after [23]: Ccp-chalcopyrite, Sp-sphalerite, Gn-galena, Py-pyrite. Icb is isocubanite. 

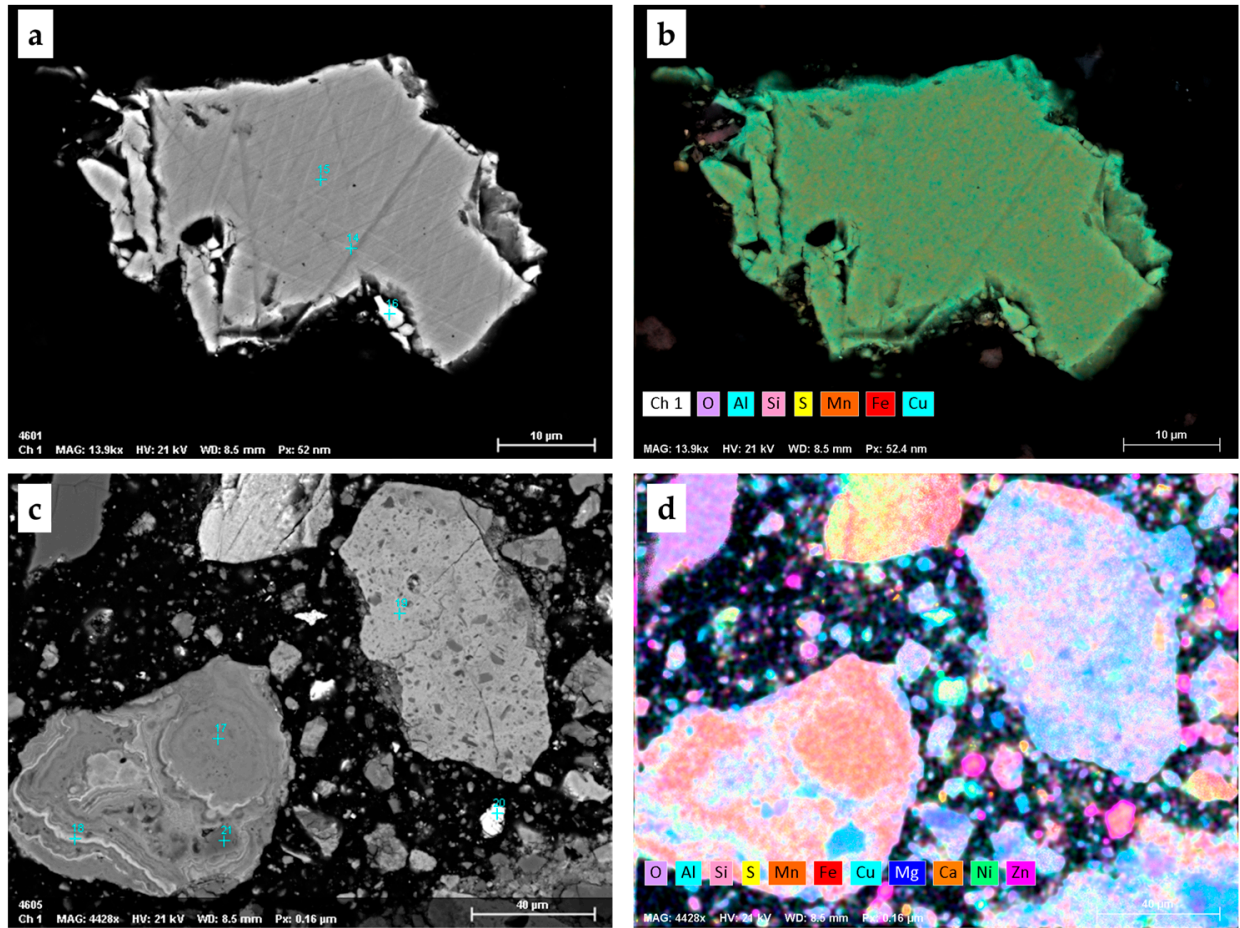

Figure 2. Scanning electron microscope (SEM) (a,c) images and energy dispersive spectroscopy (EDS) analyses $(\mathbf{b}, \mathbf{d})$ with displayed distribution of selected elements. (a,b) Isocubanite with lamellae of chalcopyrite, $(\mathbf{c}, \mathbf{d})$ heterogeneous layer growth structure of nodules.

Table 1. EDS analyses (in \%) on selected particles of a mixture of PN (67\%) and SMS (33\%). Point locations are indicated in Figure 1. Points 14-16 represent isocubanite with lamellae of chalcopyrite, point 20 is sphalerite with a high concentration of $\mathrm{Fe}$, points 17-19, 21 are from heterogeneous layer growth structure of nodules.

\begin{tabular}{|c|c|c|c|c|c|c|c|c|c|c|c|c|c|c|c|c|c|c|}
\hline Point & 0 & F & $\mathrm{Na}$ & $\mathrm{Mg}$ & Al & $\mathrm{Si}$ & $\mathbf{P}$ & $\mathrm{S}$ & $\mathrm{Cl}$ & $K$ & $\mathrm{Ca}$ & $\mathrm{Ti}$ & Mn & $\mathrm{Fe}$ & Co & $\mathrm{Ni}$ & $\mathrm{Cu}$ & $\mathrm{Zn}$ \\
\hline 14 & & & & & & & & 35.47 & & & & & & 44.94 & & & 19.32 & \\
\hline 15 & & & & & & & & 35.55 & & & & & & 45.12 & & & 19.3 & \\
\hline 16 & & & & & & & & 34.44 & & & & & & 44.86 & & & 20.7 & \\
\hline 17 & 30.29 & & 2.12 & 1.26 & 0.76 & 3.46 & 0.4 & 0.80 & & 0.44 & 4.17 & 1.05 & 39.10 & 15.53 & 0.63 & & & \\
\hline 18 & 34.37 & 2.02 & 2.09 & 1.72 & 0.58 & 1.37 & & 0.71 & 0.17 & 0.77 & 1.83 & 0.18 & 45.25 & 3.11 & 0.14 & 3.26 & 1.96 & 0.46 \\
\hline 19 & 37.87 & & 1.91 & 2.02 & 0.43 & 0.97 & & 0.11 & 0.11 & 1.1 & 1.49 & & 51.05 & & & 0.87 & 2.06 & \\
\hline 20 & & & & & & & & 33.18 & & & & & 2.19 & 16.95 & & & & 47.68 \\
\hline 21 & 46.86 & & 10.26 & & 11.98 & 30.9 & & & & & & & & & & & & \\
\hline
\end{tabular}

\subsection{Leaching}

Our previous study [8] investigated various factors such as the temperature, $\mathrm{H}_{2} \mathrm{SO}_{4}$ concentration, and dosage of $\mathrm{NaCl}$, that could influence dissolution of metals from SMS rock samples in the presence of pure manganese dioxide, as an oxidant. In this paper, we only emphasized changes in time and dosage of polymetallic nodules, while other leaching parameters, such as $1 \mathrm{M} \mathrm{H}_{2} \mathrm{SO}_{4}, 1 \mathrm{M} \mathrm{NaCl}, 80^{\circ} \mathrm{C}$, $700 \mathrm{rpm}$, solid-to-liquid ratio of $50 \mathrm{~g} / \mathrm{L}$, were kept constant.

The leaching recoveries of copper and manganese at various times and PN-to-SMS ratios are shown in Figures 3 and 4. The results show that copper was not extracted from SMS in the aqueous solution of $\mathrm{H}_{2} \mathrm{SO}_{4}(1 \mathrm{M})$ and $\mathrm{NaCl}(1 \mathrm{M})$ without polymetallic nodules. We interpret this to be due to the absence of an oxidizing agent, that is $\mathrm{MnO}_{2}$. The addition of polymetallic nodules resulted in the increased leaching of metals within the first two hours. The mechanism behind this could be either an increased dissolution due to a source of manganese dioxide, Fe as well as $\mathrm{Cu}$ and $\mathrm{Ni}$ or the result of rapid desorption of metals from the PN structure. One can see that two different stages of leaching kinetics can be distinguished (Figure 3). In the first stage, before $2 \mathrm{~h}$, copper dissolved rapidly, while after two hours, it dissolved at a relatively slow rate, ultimately reaching plateau. The leaching 
recovery of metals increased, and at the same time the content of metal in the residue decreased (Figure 4). Under the investigation conditions, Ni dissolved rapidly (Figure 3c), while Zn followed the $\mathrm{Cu}$ pattern (Figure 3d). Thus, for the sake of clarity, we only discuss the data for $\mathrm{Cu}$ and $\mathrm{Mn}$.

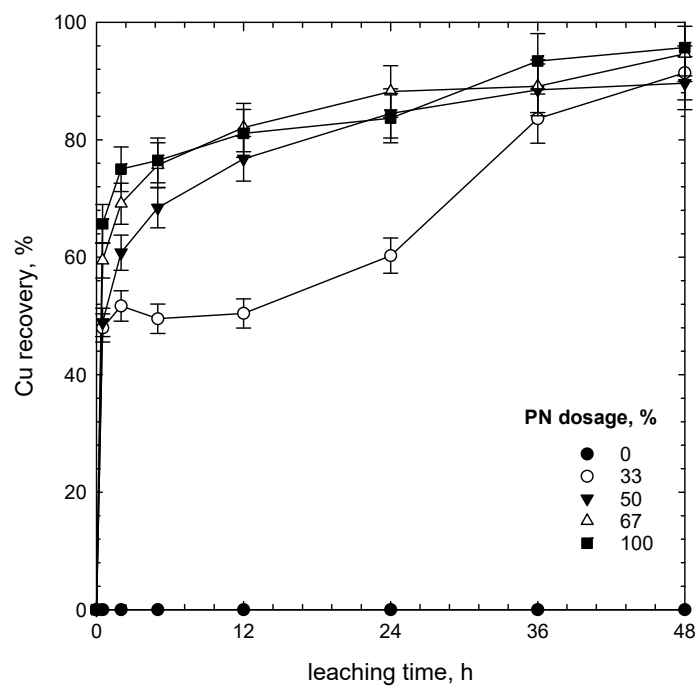

(a)

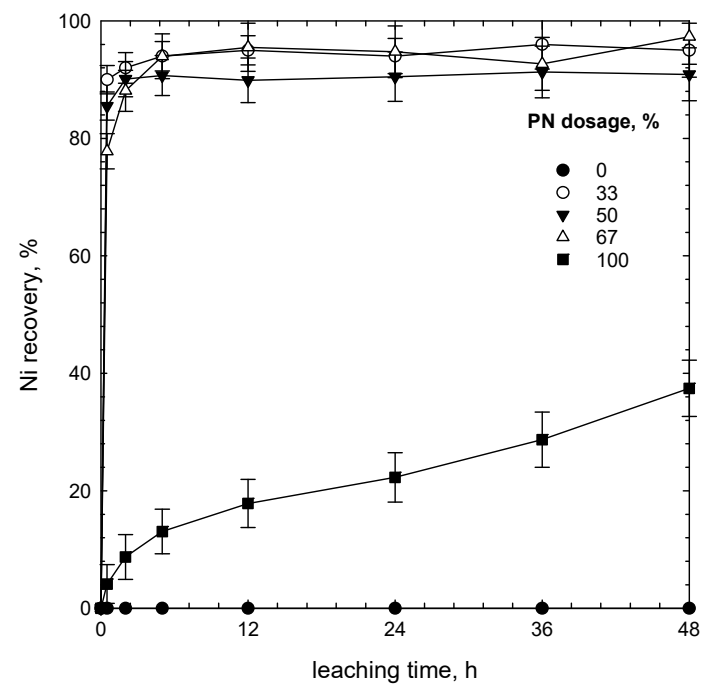

(c)

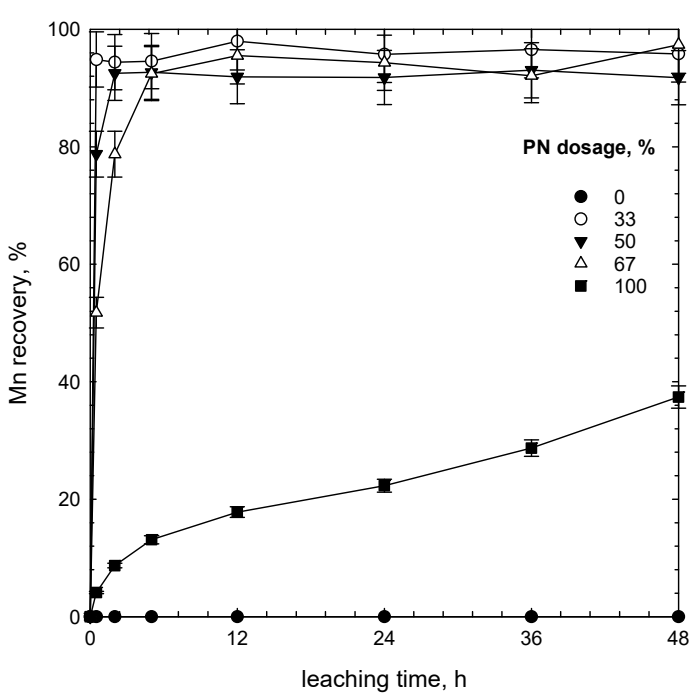

(b)

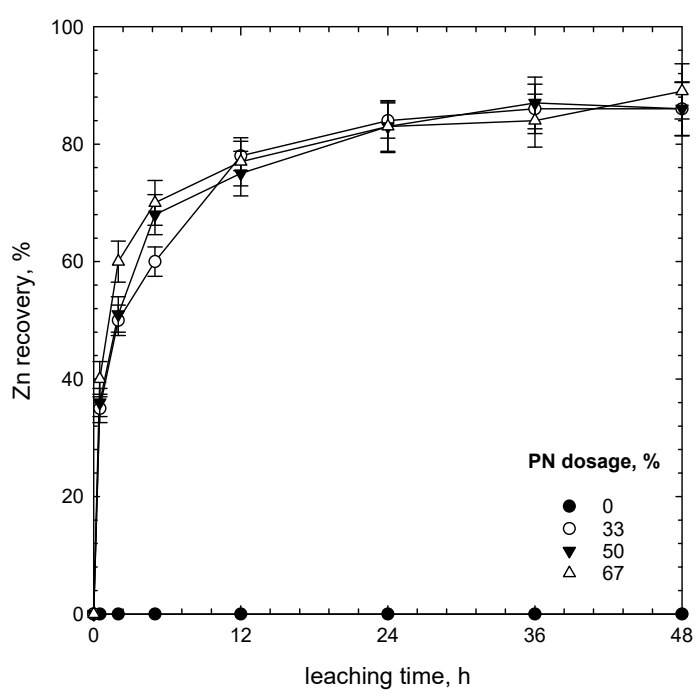

(d)

Figure 3. Effect of polymetallic nodules dosage (\%) on recovery of (a) copper, (b) manganese, (c) nickel and (d) zinc $\left(1 \mathrm{M} \mathrm{H}_{2} \mathrm{SO}_{4}, 1 \mathrm{M} \mathrm{NaCl}, 80^{\circ} \mathrm{C}\right)$.

The kinetics of copper dissolution varied with the concentration of $\mathrm{MnO}_{2}$ (Figures 3a and 4a). For the first two hours, the copper recovery changed significantly from ca. $50 \%$ to ca. $70 \%$ as the dosage of PN increased from $33 \%$ to $67 \%$. We interpret this to be due to increased concentration of $\mathrm{MnO}_{2}$, as an oxidizing agent, from ca. 7 and $14.5 \mathrm{~g} / \mathrm{L}$, respectively. A higher concentration of $\mathrm{MnO}_{2}$ and longer leaching time improved the leaching reaction of copper from chalcopyrite, isocubanite, sphalerite/chalcopyrite intergrowths as well as from the PN matrix. 


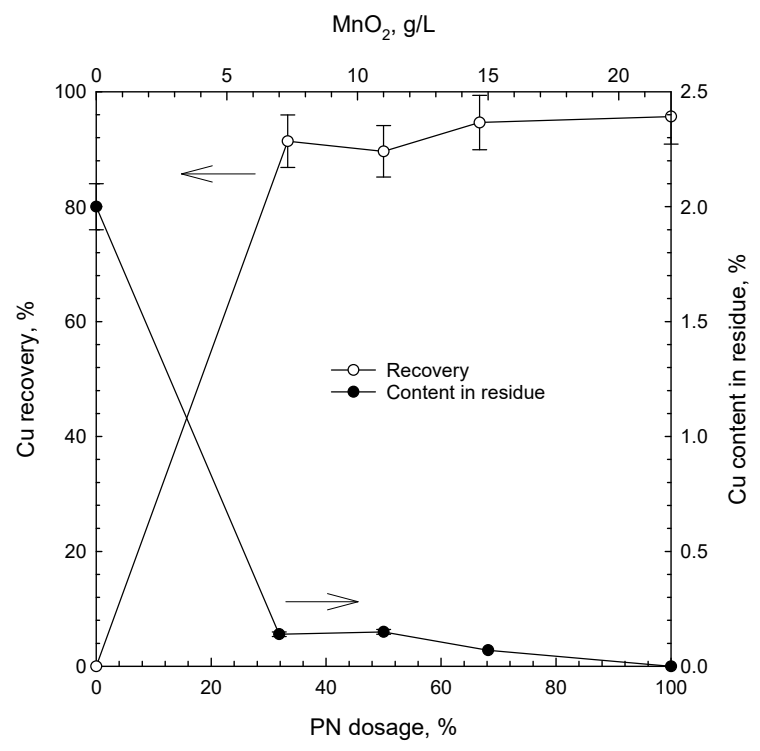

(a)

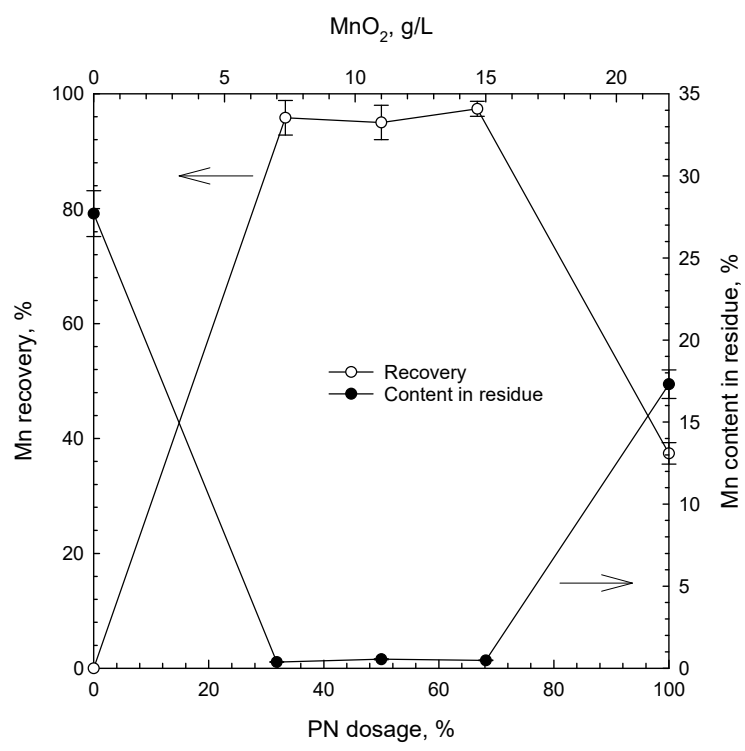

(b)

Figure 4. Leaching recovery and content in residue of (a) copper and (b) manganese in the presence of various amounts of polymetallic nodules ( $\mathrm{PN}$, in \%) and corresponding $\mathrm{MnO}_{2}(\mathrm{~g} / \mathrm{L})\left(1 \mathrm{M} \mathrm{H}_{2} \mathrm{SO}_{4}, 1 \mathrm{M}\right.$ $\mathrm{NaCl}, 80^{\circ} \mathrm{C}, 48 \mathrm{~h}$ ).

The results clearly indicate that there was only partial dissolution of manganese in the absence of SMS (PN dosage of 100\%, which corresponds to $22 \mathrm{~g} / \mathrm{L}$ of $\mathrm{MnO}_{2}$ ) (Figures 3 and 4 ). Thus, in order to dissolve manganese from PN, it was necessary to use a reducing agent. In the presence of SMS, as a source of Fe(II), irrespective of the SMS-to-PN ratio, manganese from polymetallic nodules dissolved rapidly, and almost the whole manganese was leached out within $30 \mathrm{~min}$. One can clearly see that dissolution of copper was slower than that of Mn (Figure 3). After two hours of the process, the recovery of copper was increasing slowly with the leaching time, while manganese was already dissolved. It indicates the preferential dissolution of manganese over copper under-investigated conditions. For PN, initial dissolution of major elements such as Mn and Fe affects further dissolution of minor constituents such as $\mathrm{Cu}$ and $\mathrm{Ni}$ which are finely disseminated in the PN matrix [24].

Simultaneous leaching of SMS and $\mathrm{PN}$ in the $\mathrm{H}_{2} \mathrm{SO}_{4}-\mathrm{NaCl}$ media was found to occur due to three possible routes: (i) Galvanic interactions between manganese dioxide and primary marine minerals of SMS (i.e., pyrite, isocubanite, chalcopyrite, sphalerite), (ii) the action of the $\mathrm{Fe}^{3+} / \mathrm{Fe}^{2+}$ couple, as well as iii) possible action of chlorine gas generated in the mixed sulfate-chlorite media in the presence of $\mathrm{MnO}_{2}$, which has been readily utilized in the redox reaction. The possible dissolution mechanism was described in detail elsewhere [8].

Briefly, complete dissolution of $\mathrm{Mn}$ results in reduction of manganese(IV) to manganese(II) by ferrous $\left(\mathrm{Fe}^{2+}\right)$ ions in the aqueous solution of $\mathrm{H}_{2} \mathrm{SO}_{4}$ according to the simplified reaction:

$$
\mathrm{MnO}_{2}+2 \mathrm{Fe}^{2+}+4 \mathrm{H}^{+} \rightarrow \mathrm{Mn}^{2+}+2 \mathrm{Fe}^{3+}+2 \mathrm{H}_{2} \mathrm{O}
$$

In the mixed sulfate-chloride media and the solution containing dissolved $\mathrm{MnO}_{2}$, ferrous $\left(\mathrm{Fe}^{2+}\right)$ ions could be oxidized to ferric $\left(\mathrm{Fe}^{3+}\right)$ ions, which then acted as an oxidizing agent for chalcopyrite isocubanite and sphalerite/chalcopyrite intergrowths as well as $\mathrm{PN}$ matrix. In the $\mathrm{MnO}_{2}-\mathrm{H}_{2} \mathrm{SO}_{4}-\mathrm{NaCl}$ system, dissolution of copper was also possible due to mineral surface complexation with $\mathrm{Cl}^{-}$according to the reactions:

$$
\begin{aligned}
& \mathrm{CuFeS}_{2}+4 \mathrm{Fe}^{3+} \rightarrow \mathrm{Cu}^{2+}+5 \mathrm{Fe}^{2+}+2 \mathrm{~S}^{0} \\
& \mathrm{CuFe}_{2} \mathrm{~S}_{3}+6 \mathrm{Fe}^{3+} \rightarrow \mathrm{Cu}^{2+}+8 \mathrm{Fe}^{2+}+3 \mathrm{~S}^{0}
\end{aligned}
$$




$$
\begin{gathered}
2 \mathrm{CuFeS}_{2}+5 \mathrm{Cl}_{2} \rightarrow 2 \mathrm{CuCl}_{2}^{+}+2 \mathrm{FeCl}_{3}+4 \mathrm{~S}^{0} \\
\mathrm{CuFe}_{2} \mathrm{~S}_{3}+4 \mathrm{Cl}_{2} \rightarrow \mathrm{CuCl}_{2}^{+}+2 \mathrm{FeCl}_{3}+3 \mathrm{~S}^{0}
\end{gathered}
$$

Based on the XRD data of the leachate residue (Figure 5) the leaching process yielded sulfur in its elemental form, confirming the aforementioned reactions.

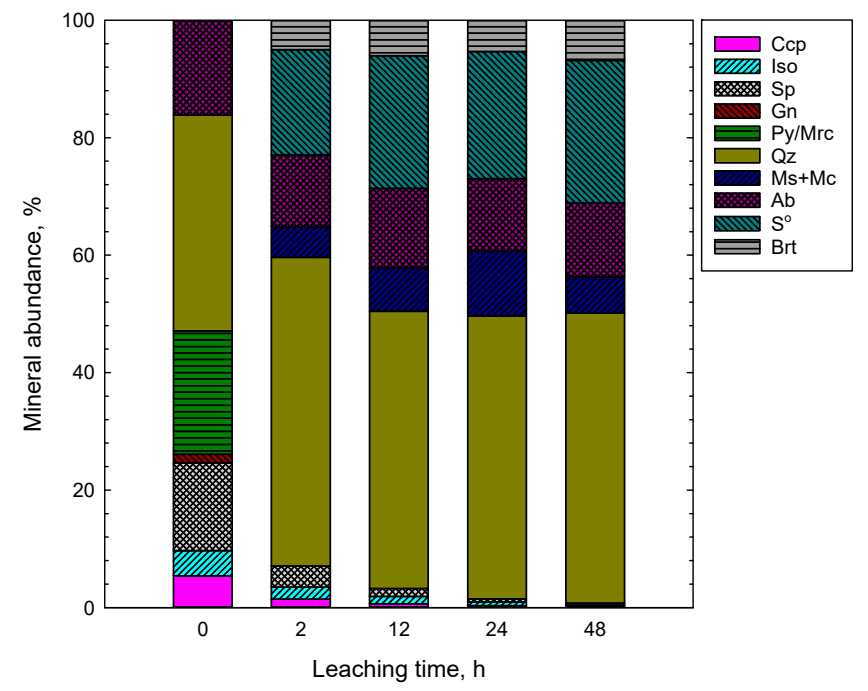

Figure 5. Mineral distribution (semi-quantitative XRD) in the feed (0) and leaching residues $\left(1 \mathrm{M} \mathrm{H}_{2} \mathrm{SO}_{4}\right.$, $\left.1 \mathrm{M} \mathrm{NaCl}, 80^{\circ} \mathrm{C}, 67 \% \mathrm{PN}, 33 \% \mathrm{SMS}\right)$. Abbreviations after [23]: Ccp-chalcopyrite, Sp-sphalerite, Gn—galena, Py—pyrite, Mrc—marcasite, Qz-quartz, Ms—muscovite, Mc—microcline, Ab-albite, Brt-barite. Iso is isocubanite, and $\mathrm{S}^{0}$ is elemental sulfur.

The results also indicate that copper was dissolved from PN in the mixed sulfate-chlorite media without SMS, while the recovery of manganese remained very low in the absence of the reducing agent (Figures 3 and 4). High copper recovery may result from involvement of $\mathrm{H}^{+}$and $\mathrm{Cl}^{-}$in the surface reaction and dissolution of copper oxide according to the simplified reaction:

$$
\mathrm{CuO}+2 \mathrm{H}^{+} \rightarrow \mathrm{Cu}^{2+}+\mathrm{H}_{2} \mathrm{O}
$$

Moreover, the presence of ferric(III) oxyhydroxide (goethite) in the PN matrix, which dissolves according to the reaction:

$$
\mathrm{FeOOH}+3 \mathrm{H}^{+} \rightarrow \mathrm{Fe}^{3+}+2 \mathrm{H}_{2} \mathrm{O}
$$

could facilitate complete dissolution of copper oxide species from PN. Low recovery of Mn resulted from the existence of stable $\mathrm{MnO}_{2}, \mathrm{Mn}_{3} \mathrm{O}_{4}, \mathrm{MnOOH}$ species [24].

\subsection{Mineralogical Analyses of Feed and Residues}

The mineralogy of the feed, consisting of $67 \%$ PN and 33\% SMS, and leaching residues was investigated to reveal the effect of time on mineral phase changes during simultaneous leaching of SMS and PN. The XRD and automated mineralogy (Zeiss Mineralogic Mining, AM) analyses, in the form of mineral abundance, are presented in Figures 5 and 6, respectively. Due to the complex structure of PN, with typical grain size less than the $3 \mu \mathrm{m}$ analytical step size (pixel spacing) in AM, it was impossible to distinguish different types of silicates using AM. Since the leaching feed sample was very amorphous, the presented XRD results are semi-quantitative. Thus, both methods have been used to strengthen the results and discussion. Furthermore, AM provides information on the elemental deportment, which can be found in Figure 7. 


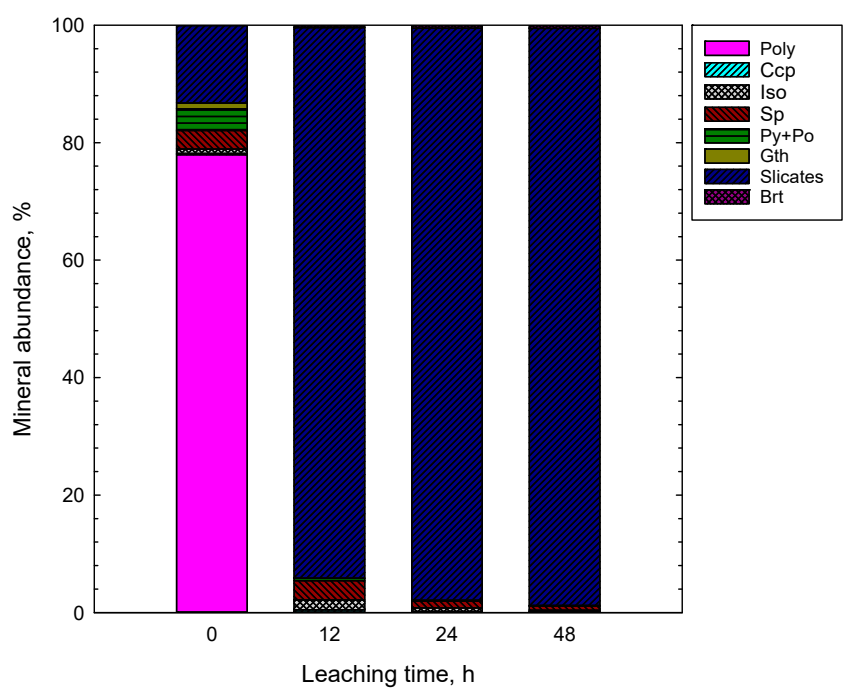

Figure 6. Mineral distribution (automated mineralogy) in the feed (0) and leaching residues $\left(1 \mathrm{M} \mathrm{H}_{2} \mathrm{SO}_{4}\right.$, $\left.1 \mathrm{M} \mathrm{NaCl}, 80^{\circ} \mathrm{C}, 67 \% \mathrm{PN}, 33 \% \mathrm{SMS}\right)$. Abbreviations after [23]: Ccp-chalcopyrite, Sp-sphalerite, Py-pyrite, Po—pyrrhotite, Gth—goethite, Brt—barite. Poly represents heterogeneous layer growth structure of nodules, while Iso is isocubanite.

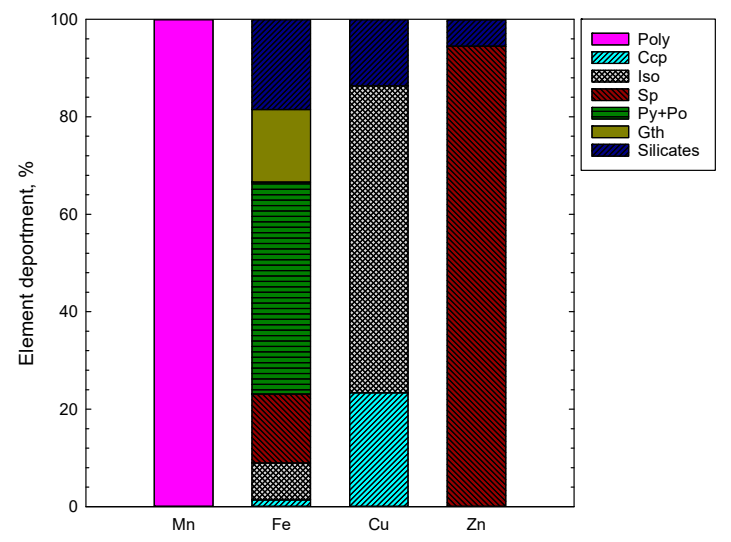

(a)

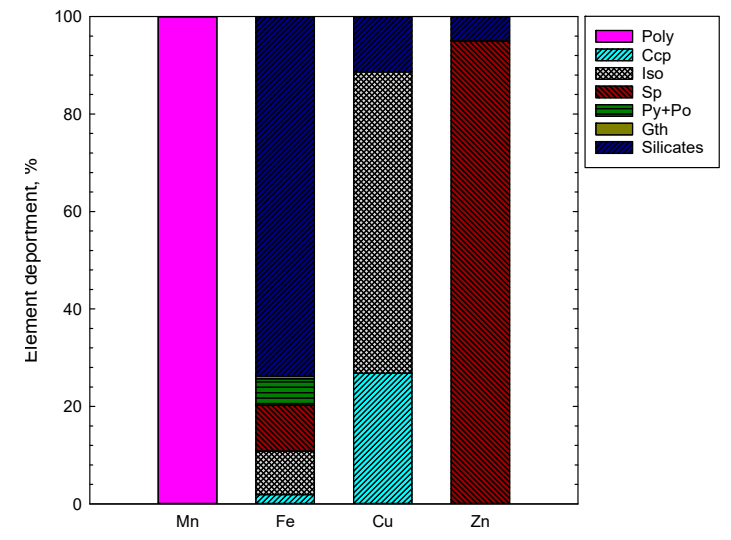

(b)

Figure 7. $\mathrm{Mn}, \mathrm{Fe}, \mathrm{Cu}$ and $\mathrm{Zn}$ deportment (calculated by automated mineralogy) in (a) feed (PN (67\%) and SMS (33\%)), and (b) leaching residue after 48 h. Abbreviations after [23]: Ccp-chalcopyrite, $\mathrm{Sp}$-sphalerite, $\mathrm{Py}$ - pyrite, Po-pyrrhotite, Gth—goethite. Poly is heterogeneous layer growth structure of nodules, Iso is isocubanite.

According to the XRD analyses (Figure 5), the feed sample (depicted as 0) contained significant quantities of pyrite/marcasite/pyrrhotite (ca. 21\%), chalcopyrite (ca. $5.4 \%$ ), isocubanite (ca. $4.3 \%$ ) with silicates (ca. 53\%) such as quartz, albite, muscovite and microcline as a gangue material. The automated mineralogy analyses revealed the presence of ca. $1 \%$ goethite in the feed sample, which was not found by XRD. As shown in Figure 2c,d, the typical heterogeneous layer growth structure of nodules, that is the crystal structure of Mn-oxides and Mn-Fe(oxy) hydroxides, were intergrown on a submicron scale. Thus, the polymetallic nodule structure was depicted by the automated mineralogy as a mixed polymetallic (Poly) phase (Figure 6). The analyzed by XRD silicate minerals were grouped into one group in the AM analysis (Figure 6).

The distribution of elements in the leaching feed, obtained from the automated mineralogy, revealed that manganese occurs only within the heterogeneous layer growth structure of nodules (Figure 7), and its content ranges from ca. 40 to ca. 51\%. Copper was found to be distributed among chalcopyrite (ca. 24\%) and isocubanite (ca. 63\%), in addition to being associated with Fe-silicates 
(ca. 13\%), being a part of the PN matrix. The submicron inclusions of chalcopyrite in sphalerite were not detected by automated mineralogy ( $3 \mu \mathrm{m}$ pixel spacing), thus no copper deportment in sphalerite was reported. Zinc occurs mainly in sphalerite (ca. 95\%) with minor presence in Fe-silicates. Iron was distributed among iron sulfides (pyrite/marcasite ca. 38\%, pyrrhotite ca. 6\%), silicates (ca. 18\%), goethite (ca. 15\%), sphalerite (ca. 14\%), isocubanite (ca. 7\%) and chalcopyrite (ca. 1\%).

As indicated by the XRD and AM findings, the mineral composition of residues changed with the leaching time (Figures 5-8). The leaching caused a significant reduction in the amount of sulfides in the solid phase and resulted in concentrations of $15 \%, 7 \%, 3 \%$ and $1 \%$ after 2, 12, 24 and $48 \mathrm{~h}$, respectively (XRD, Figures 5 and 7a). Pyrite/marcasite, pyrrhotite, and goethite were rapidly dissolved being utilized for leaching of Mn-oxide species from PN (Figures 5 and 6). The proportion of iron deportment in the leaching residues changed significantly. In the residue after $48 \mathrm{~h}$, iron occurred mostly in silicates (ca. 75\%), with only a minor proportion ( $<1 \mathrm{wt} \%$ ) attributed to sulfides (Figure 7).
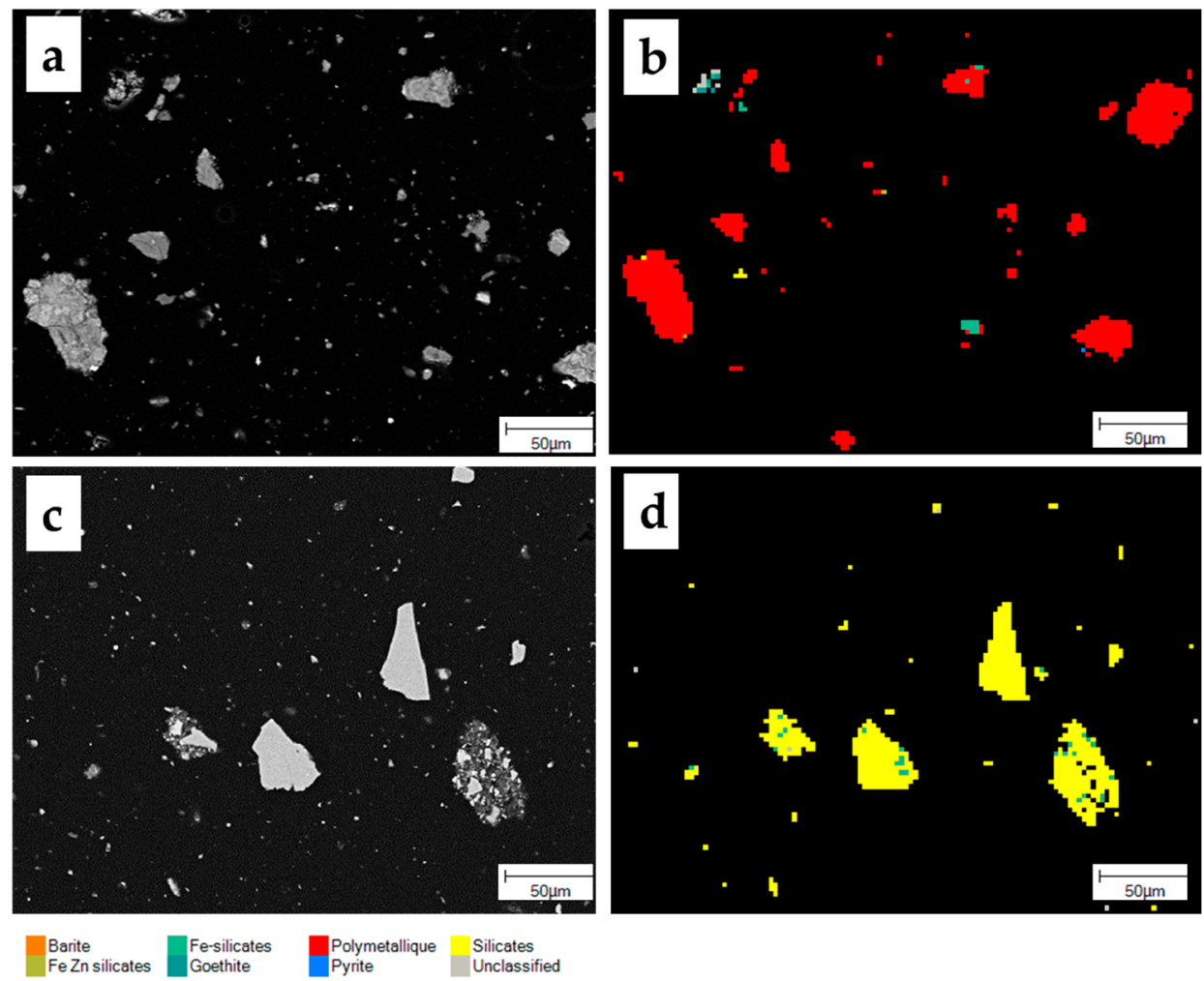

Figure 8. False-color mineral maps as obtained by automated mineralogy of selected areas of $(\mathbf{a}, \mathbf{b})$ feed $(\mathrm{PN}(67 \%)$ and SMS $(33 \%))$ and $(\mathbf{c}, \mathbf{d})$ residue after $48 \mathrm{~h}$.

The XRD results show that the leaching process yielded elemental sulfur (Figure 5). The sulfides were readily oxidized to form elemental sulfur, which comprised ca. 22-24\% of the leaching residues. Some sulfur might also get oxidized to sulfates, generating sulfuric acid. It should be noted that elemental sulfur was only detected by XRD (a lack of $S^{0}$ detection by MA might be a result of either its rapid oxidation or removal during the sample preparation for $\mathrm{MA}$ ). One should also note that jarosite was not found by either mineralogical method. Thus, it confirms the aforementioned reactions, and proves that in the mixed sulfate-chloride systems in the presence of $\mathrm{MnO}_{2}$ jarosite does not precipitate and elemental sulfur is the only product of sulfides dissolution.

The silicates were more abundant compared to the feed sample, and their proportion increased with the leaching time (Figures 6 and 7). As revealed by mineralogical observations, after $48 \mathrm{~h}$ of leaching, the residue sample was mostly composed of silicates, elemental sulfur, and barite. These mineralogical phases are not reactive to the leaching process. 
After leaching there was only a slight reduction in the grain size (from $d_{50} 10$ to $8 \mu \mathrm{m}$ ). The remaining grains were extremely fine and locked in coarser grains of silicates (Figure 8).

\section{Conclusions}

Simultaneous processing of seafloor massive sulfides (SMS) and polymetallic nodules (PN) was studied in this paper. Leaching experiments were conducted using sulfuric acid and sodium chloride at different ratios of PN-to-SMS. It was shown that simultaneous leaching of two different types of marine resources was possible, resulting in high extraction of metals. The mineralogical investigations revealed that leaching residues consisted of silicates (quartz, muscovite, microcline, albite) in addition to elemental sulfur and barite, with trace abundance in sulfides ( $<1 \mathrm{wt} \%)$. These products might be purified using physical and physicochemical methods, and then utilized for various applications, including: Electronics and glass/ceramic production (silicates), oil and gas drilling (baryte) as well as sulfuric acid production and polymeric materials (sulfur, [25]). They could also be utilized as heavy metal absorbents (e.g., [26]). Metals from the leachate might be extracted through different methods among which solvent extraction and electrowinning are widely used. The leach solution would be recycled to the head of the process. The simplified conceptual flowsheet is presented in Figure 9.

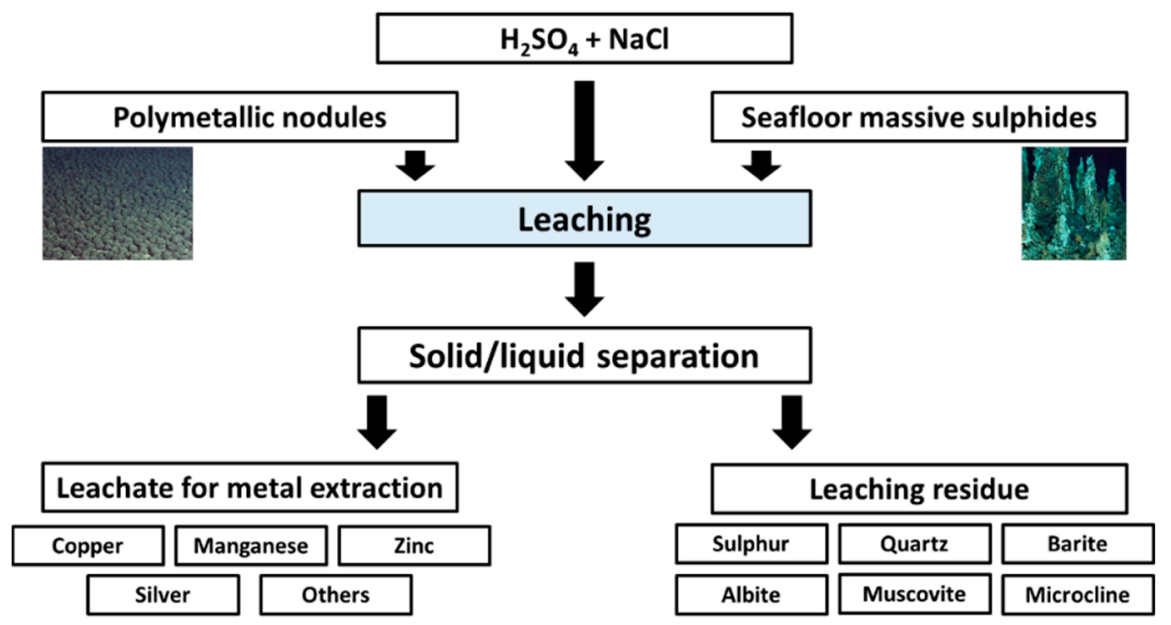

Figure 9. Simplified conceptual flowsheet of simultaneous leaching of seafloor massive sulfides (SMS) and polymetallic nodules (PN).

Simultaneous leaching of marine minerals has many advantages as it results in high extraction of metals, and also the need for additional oxidizing and reducing agents is reduced resulting in a less expensive and more environmentally friendly process. For SMS-PN in the mixed sulfate-chloride system, the process does not require pyrometallurgical pretreatment, thus the environmental impact can be significantly reduced. Moreover, due to high costs of hydrochloric acid, the addition of sodium chloride offers the possibility of an efficient and less expensive leaching process.

Author Contributions: Conceptualization, P.B.K.; methodology, P.B.K.; formal analysis, P.B.K.; investigation, P.B.K. and H.B.; writing—original draft preparation, P.B.K.; writing一review \& editing, P.B.K., H.B., R.A.K., K.A.; visualization, P.B.K.; supervision, R.A.K.; funding acquisition, K.A.

Funding: This work was funded by the Research Council of Norway (Norges Forskningsråd, NFR) Project No. 247626/O30. The industrial partners are acknowledged for co-funding the project.

Acknowledgments: The authors gratefully acknowledge Torill Sørløkk and Laurentius Tijhuis, NTNU for their technical assistance with XRF, ICP-MS and XRD, as well as Ben Snook and Kristian Drivenes for their help in mineralogical characterization of the SMS and PN samples. Further thanks go to Global Sea Mineral Resources (GSR), DEME Group and Aleksandra Lang for providing the polymetallic nodule samples. The authors would also like to thank five anonymous reviewers for their detailed and constructive comments.

Conflicts of Interest: The authors declare no conflict of interest. 


\section{References}

1. Lusty, P.A.J.; Murton, B.J. Deep-ocean mineral deposits: metal resources and windows into Earth processes. Elements 2018, 14, 301-306. [CrossRef]

2. Sharma, R. Deep-Sea Mining: Current Status and Future Considerations. In Deep-Sea Mining Resource Potential, Technical and Environmental Considerations; Sharma, R., Ed.; Springer International Publishing AG: Cham, Switzerland, 2018.

3. Lodge, M.W.; Verlaan, P.A. Deep-sea mining: International regulatory challenges and responses. Elements 2018, 14, 331-336. [CrossRef]

4. Drzymala, J. Mineral Processing. Foundations of Theory and Practice of Metallurgy; Oficyna Wydawnicza Politechniki Wroclawskiej: Wroclaw, Poland, 2007.

5. Gupta, C.K. Chemical Metallurgy: Principles and Practice; John Wiley \& Sons: New Jersey, NJ, USA, 2006.

6. Nakajima, Y.; Uto, S.; Kanada, S.; Yamamoto, J.; Takahashi, J.; Otabe, S.; Sadaki, J.; Okaya, K.; Matsuo, S.; Fujita, T. Concept of seafloor mineral processing for development of seafloor massive sulfides. In Proceedings of the ASME 30th International Conference on Ocean, offshore and Arctic Engineering, Rotterdam, The Netherlands, 19-24 June 2011.

7. Kowalczuk, P.B.; Snook, B.; Kleiv, R.A.; Aasly, K. Efficient extraction of copper and zinc from seafloor massive sulphide rock samples from the Loki's Castle area at the Arctic Mid-Ocean Ridge. Miner. Eng. 2018, 115, 106-116. [CrossRef]

8. Kowalczuk, P.B.; Manaig, D.O.; Drivenes, K.; Snook, B.; Aasly, K.; Kleiv, R.A. Galvanic leaching of seafloor massive sulphides using $\mathrm{MnO}_{2}$ in $\mathrm{H}_{2} \mathrm{SO}_{4}-\mathrm{NaCl}$ media. Minerals 2018, 8, 235. [CrossRef]

9. Havlik, T.; Laubertova, M.; Miskufova, A.; Kondas, J.; Vranka, F. Extraction of copper, zinc, nickel and cobalt in acid oxidative leaching of chalcopyrite at the presence of deep-sea manganese nodules as oxidant. Hydrometallurgy 2005, 77, 51-59. [CrossRef]

10. Nakazawa, H.; Hareyama, W. Galvanic leaching of chalcopyrite using manganese oxides in spent zinc-carbon batteries. Resour. Process. 2016, 63, 3-11. [CrossRef]

11. Wang, S.F.; Xiao, L.; Li, Y.Q.; Fang, Z.; Qiu, G.Z.; Li, J. Electronegative leaching for sphalerite-MnO $\mathrm{Mn}_{2}$ in presence of acidithiobacillus ferrooxidants. J. Therm. Anal. Calorim. 2009, 95, 601-604. [CrossRef]

12. Nayak, B.B.; Mishra, K.G.; Paramguru, R.K. Kinetics and mechanism of $\mathrm{MnO}_{2}$ dissolution in $\mathrm{H}_{2} \mathrm{SO}_{4}$ in the presence of pyrite. J. Appl. Electrochem. 1999, 29, 191-200. [CrossRef]

13. Lu, Z.Y.; Jeffrey, M.I.; Lawson, F. The effect of chloride ions on the dissolution of chalcopyrite in acidic solutions. Hydrometall. 2000, 56, 189-202. [CrossRef]

14. Dutrizac, J.E.; MacDonald, R.J.C.; Ingraham, T.R. The kinetics of dissolution of cubanite in aqueous acidic ferric sulfate solutions. Metall. Trans. 1970, 1, 3083-3088.

15. Veloso, T.C.; Peixoto, J.J.M.; Pereira, M.S.; Leao, V.A. Kinetics of chalcopyrite leaching in either ferric sulphate or cupric sulphate media in the presence of $\mathrm{NaCl}$. Int. J. Miner. Process. 2016, 148, 147-154. [CrossRef]

16. Pedersen, R.B.; Rapp, H.T.; Thorseth, I.H.; Lilley, M.D.; Barriga, F.J.A.S.; Baumberger, T.; Flesland, K.; Fonseca, R.; Fruh-Green, G.L.; Jorgensen, S.L. Discovery of a black smoker vent field and vent fauna at the Arctic Mid-Ocean Ridge. Nat. Commun. 2010, 1, 126. [CrossRef]

17. Ludvigsen, M.; Aasly, K.; Ellefemo, S.; Hilario, A.; Ramirez-Llodra, E.; Søreide, F.; Falcon-Suarez, I.; Juliani, C.; Kieswetter, A.; Lim, A.; et al. NTNU Cruise Reports 2016 No 1 MarMine Arctic Mid Ocean Ridge 15.08.2016-05.09.2016; NTNU: Trondheim, Norway, 2016; ISSN 2535-2520.

18. Snook, B.; Drivenes, K.; Rollinson, G.; Aasly, K. Characterisation of Mineralised Material from the Loki's Castle Hydrothermal Vent on the Mohn's Ridge. Minerals 2018, 8, 576. [CrossRef]

19. Bouzahzah, H.; Benzaazoua, M.; Mermillod-Blondin, R.; Pirard, E. A novel procedure for polished section preparation for automated mineralogy avoiding internal particle settlement. In Proceedings of the 12th International Congress for Applied Mineralogy (ICAM), Istanbul, Turkey, 10-12 August 2015.

20. Santoro, L.; Tshipeng, S.; Pirard, E.; Bouzahzah, H.; Kaniki, A.; Herrington, R. Mineralogical reconciliation of cobalt recovery from the acid leaching of oxide ores from five deposits in Katanga (DRC). Miner. Eng. 2019, 137, 277-289. [CrossRef]

21. Abramovski, T.; Stefanova, V.P.; Causse, R.; Romanchuk, A. Technologies for the processing of polymetallic nodules from Clarion Clipperton Zone in the Pacific Ocean. J. Chem. Technol. Metall. 2017, 52, 258-269.

22. Mineralogy Database. Available online: http://webmineral.com/ (accessed on 5 July 2019). 
23. Whitney, D.L.; Evans, B.W. Abbreviations for names of rock-forming minerals. Am. Miner. 2010, 95, $185-187$. [CrossRef]

24. Senanayake, G. Acid leaching of metals from deep-sea manganese nodules-A critical review of fundamentals and applications. Miner. Eng. 2011, 24, 1379-1396. [CrossRef]

25. Chung, W.J.; Griebel, J.J.; Kim, E.T.; Yoon, H.; Simmonds, A.G.; Ji, H.J.; Dirlam, P.T.; Glass, R.S.; Wie, J.J.; Nguyen, N.A.; et al. The use of elemental sulfur as an alternative feedstock for polymeric materials. Nat. Chem. 2013, 5, 518-524. [CrossRef] [PubMed]

26. Vu, N.H.; Kristianová, E.; Dvořák, P.; Abramowski, T.; Dreiseitl, I.; Adrysheva, A. Modified Leach Residues from Processing Deep-Sea Nodules as Effective Heavy Metals Adsorbents. Metals 2019, 9, 472. [CrossRef]

C 2019 by the authors. Licensee MDPI, Basel, Switzerland. This article is an open access article distributed under the terms and conditions of the Creative Commons Attribution (CC BY) license (http://creativecommons.org/licenses/by/4.0/). 